\title{
EFFECTS OF USING DIFFERENT LEVELS OF DIETARY SUPPLEMENTATION OF SOME PROBIOTICS AS GROWTH PROMOTERS IN DIETS ON GROWTH PERFORMANCE, FEED UTILIZATION, BODY BIOCHEMICAL COMPOSITIONAND IMMUNE OF MONOSEX ALL MALE NILE TILAPIA (OREOCHROMISNILOTICUS) FINGERLINGS
}

\author{
Ahmad, M. E ${ }^{1}$, Mohsen S. Hussein ${ }^{1}$ and Gaber D. Ibrahim ${ }^{2}$ \\ 1. Fish production, Dept. of Animal Production, Faculty of Agriculture, Al-Azhar University, \\ Cairo, Egypt. \\ 2. Dept. of Fish Nutrition, Faculty of Environ. Agri. Sc., Suez Canal University, El-Arish, \\ North Sinai, Egypt.
}

\begin{abstract}
The present experiments were conducted at the experimental fish culture fiberglass tanks with closed a water recirculation system, belonging to the fish production section, Animal production department, faculty of agriculture, Al-Azhar University, Cairo, Egypt. The experiments lasted for 90 days, using three commercial probiotics (Biogen, Premalac and Lacto Cel- con) as growth promoters in diets to study their effects on Growth Performance, Feed Utilization, Body Biochemical Composition and immune of monosex Nile Tilapia (Oreochromis niloticus) Fingerlings . Each one of these probiotics was applied in tilapia basal diets at three levels being 1,2 , and $3 \mathrm{~g} / \mathrm{kg}$ diet as recommended by the producers. The experiments were conducted in $4 \times 3$ factorial design and included ten treatments each in three replicates (tank). A total number of 750 sex-reversed all male Nile tilapia (Oreocheromisniloticus) fingerlings (25 fingerlings / tank , 3 tanks for control and 27 tanks for three experiments ), each block included control one were fed to fish basal diet as triplicates and assigned for one of the three tested commercial probiotics, with the same initial average weights and with same average total length.

All results indicated that either Biogen or Lacto- Cel - con* at $3 \mathrm{~g} / \mathrm{kg}$ produced a positive effect on growth and feed utilization of tilapia fingerlings. In addition, the immune responses were substantial in both treatment groups following the challenge with bacterial disease. However, the probiotic Biogen or Lacto- Cel - con* when added to fish diet at $3 \mathrm{~g} / \mathrm{kg}$, produced a steady improvement of tilapia growth compared to Premalac. Meanwhile, both were superior than using Premalac as commercial probiotics. Lacto- Cel - con*and Biogen*were clearly beneficial for cultured $O$. niloticus when administered as a food additive. It is argued that such probiotic has a role in disease control strategies, growth promotion and immunostimulation. Further studies are needed in this field as this strategy strengthens and help understanding the role of probiotics looking for the alternative health management strategy for developing aquaculture productivity.
\end{abstract}

Key words: Probiotics Preparations, Growth performanc, Feed utilization, Body composition and Immune response, Oreochromis niloticus fingerlings. 


\section{INTRODUCTION}

Egypt is one of the major contributors to the world aquaculture projects. Production from both wild fishing and aquaculture are of premium importance on fresh and marine continents $\mathbf{A q u}$, Gafrd (2006).

A culture development has accelerated throughout the country, since 1982, it has accounted for more than $70 \%$ of the country's aquatic production, making Egypt the largest producer of aquatic products in Africa and in high rank production in the world FAO (2011). As fast growing sector, the desire for more and efficient production with minimal hindrances forced the producers to seek for health strategies that medley both fish and consumers.

Feed in aquaculture plays an important role in the production cycle and exert threshold on both practical and economic aspects. Feed additive sectors are expanding day after day to achieve better growth and health for fish and shrimp and to meet the potential requirements of the culturists.

In last decade, the search of new options, several studies have been carried out to test new compounds, from which the aquaculture industry has developed the concept of "functional additives".

Among these additives, the additions of microorganisms to diets, named probiotics, has shown to improve the energy expenditure derived from other sources such as carbohydrates and increase the incorporations of protein for growth; increase the immunity and disease resistance of host organism. (LaraFlores 2012).

The term "probiotic" comes from Greek pro and bios meaning "prolife (Schrezenmeir and De Vrese, 2001) having different meanings over the years.
In 1905, Dr. Elie Metchnikoff was the first to describe the positive role played by some bacteria among farmers who consumed pathogen-containing milk and that "reliance on gut microbes for food makes it possible to take steps to change the flora of our bodies and to replace harmful microbes by beneficial microbes (Metchnikoff 1907).

Microbial feed supplement which beneficially affects the host animal by improving its intestinal balance".

This definition is still widely referred to, despite continual contention with regard to the correct definition of the term. Current probiotic applications and scientific data on mechanisms of action indicate that non-viable microbial components act in a beneficial manner and this benefit is not limited just to the intestinal region (Salminen et al., 1999).

Most studies concerned with the effects of probiotics on cultured aquatic animals have emphasized a reduction in mortality or, conversely, increased survival (Change and Liu, 2002), improved resistance against disease (Villamil et al., 2003); enhance the ability to adhere and colonize the gut (Abo-State 2009); improved the ability to antagonize other organisms (Li et al., 2004; Panigrahi et al., 2005 and Shelby et al., 2006) also, the ability to reduce the number of bacterial cells in kidneys (Park et al., 2001), the production of polyamines and digestive enzyme activity (Hidalgo et al., 2006) and the development of the nonspecific immune system by means of Cellular systems like increased phagocytic and lysozyme activities (Irianto and Austin, 2002).

Another proposed definition of probiotics used in aquaculture is "live microbial cultures added to feed or environment (water) to increase viability (survival) of the host" (Ringo et al., 2010). 
They are also refer to as bio-proteins containing living microbial cells that optimize the colonization and composition of the growth and gut microflora in animals and stimulate digestive processes and immunity.

The use of probiotics in aquaculture is now widely accepted with an increasing demand for environment friendly aquaculture (Vine et al., 2006; Wang, 2007 and Qi et al., 2009).

Nowadays, a number of preparations of probiotics are commercially available and have been introduced to fish, shellfish and molluscan farming as feed additives, or are incorporated in pond water. According to Gatesoupe (1999), the first application of probiotics in aquaculture was in the mid-1980s (Kozasa, 1986) and since then interest in such environment-friendly treatments has increased rapidly. Probiotics have been widely used as dietary supplementations in aquaculture to control of disease and also to the increase of feed efficiency and husbandry parameters (Jovanović et al., 2011).

As has been pointed out by numerous researchers (Merrifield et al., 2010a).

More possible benefits for fish linked to the administration of probiotics have been suggested: B. subtilis and B. licheniformis fed fish displayed a significant improvement of feed conversion ratio (FCR), specific growth rate (SGR) and protein efficiency ratio (Merrifield et al, 2010). Other protective mechanisms of probiotics against pathogens are production of inhibitory compounds with antibacterial activities and effects on the immune responses, such as modulation of the white blood cell counts.

The study of the effects of probiotics supplemented in the diet of tilapia has not advanced as far as it has in other species, such as salmonids (Merrifield et al., 2010).
By comparison, the available research with tilapia is severely lacking, underscoring that more research is required. However, research on the supplementation of probiotics in the diets of tilapia is advancing rapidly with the majority of studies taking place since the mid-2000s, and further advances are likely to occur in the coming years. Eid and mohamed (2008) concluded that the positive influence of additions (Biogen ${ }^{\circledR}$ and Pronifer ${ }^{B}$ ) on growth performance of monosex fingerlings Nile tilapia diets showed positive effects. From feed utilization data and the economical point of view the diet supplemented with $0.1 \%$ Biogen ${ }^{\circledR}$ was the best treatment. Ali. et al.,, (2010) found that all results indicated that either Biogen or Premalac at $2 \mathrm{~g} / \mathrm{Kg}$ produced a positive effect on growth and feed utilization of tilapia fingerlings.

In addition, the immune responses were substantial in both treatment groups following the challenge with bacterial infection. However, the probiotics Biogen when added to fish diet at $2 \mathrm{~g} / \mathrm{Kg}$, produce a steady improvement of tilapia growth compared to Premalac. Mehrim (2011) concluded that, it could be recommended the useful dietary supplementation of commercial probiotic Biogen ${ }^{\circledR}$ at a level of $0.3 \%$ with stoking density of $30 \mathrm{fish} / \mathrm{m}^{3}$ of mono-sex Nile tilapia fingerlings. This treatment realized the best growth performance, carcass composition, blood hematological and biochemical parameters, histometric characteristics of fish dorsal muscles and economic efficiency without any adverse effects on water quality criteria.

Yet, it could be required a lot of scientific efforts to maximize the commercial benefits from the environmentally-friendly commercial or natural probiotics with the local fish species.

Furthermore, the non-specific immune system can be stimulated by probiotics. Rengpipat et al. (2000) indicated that the use of Bacillus sp. in tiger shrimp provided disease protection by activating 
both cellular and humoral immune defenses.

In a recent study, investigated the effect of AquaStar ${ }^{\circledR}$ Growout (Biomin $\mathrm{GmbH}$, Austria) in white shrimp (Litopenaeusvannamei) production performance parameters. In the economically important panaeid shrimp, Vibrio species have become a major constraint on production and trade during the past two decades.

They are responsible for several diseases and mortalities of up to 100 percent, causing global losses of around US\$ three billion (Lara-Flores, 2012). Thus, there is clearly a need in increasing our knowledge of aquacultural animals and of effective preparation, technological applications and safety evaluation of probiotics.

The aim of this study is to find out the effect of different levels of three commercial probiotics (Biogen, Premalac and Lactocelcon) preparations supplemented to diets as growth promoters on growth performance, feed utilization efficiency, and immune response of monosex male Nile tilapia, Oreochromis niloticus fingerlings.

\section{MATERIALS AND METHODS}

The present experiments were conducted at the experimental fish culture fiberglass tanks with closed a water recirculation system, belonging to the fish production section, Animal production department, faculty of agriculture, Al-Azhar University, Cairo, Egypt. The experiment lasted for 90 days (from $15^{\text {th }}$ May, 2012 to $18^{\text {th }}$ Aug. 2012).

\section{Experimental Aquaculture Units:}

The experimental rearing system consisted of a series of 30 rectangular fiberglass tanks (in triplicate) each of total volume of one $\mathrm{m} 3(1 \mathrm{~m} \mathrm{x}$ $2 \mathrm{~m} \times 0.5 \mathrm{~m}$ ) in a closed recycling water system. The water supply of these tanks is the drinking tap water which derived the mechanical filter reservoir via a pump to another two fiberglass tanks of $5 \mathrm{~m} 3$ capacity.

A series of fiberglass tanks connected together with a tap water supply as well as a drainage system and connected with a mechanical filter. All experimental tanks were supplied with air through an aeration system which connected with an oil free air compressor (30hv).

Tap water have been stored for two days in two fiberglass tanks of $5 \mathrm{~m} 3$ capacity for dechlorination and for filling the experimental tanks and replacing the changed water at $(100 \%$ of tank water twice/week).

\section{Experimental Fish and maintenance:}

In this research we have choose Tilapia which is the second largest in the world, after carp, for the importance of aquaculture activities. Among these three species recognized the potential of aquaculture,the Nile tilapia, $\mathrm{O}$. niloticus,is by far the one most used in aquaculture worldwide (FAO, 2002).

The fish used in this study were sex-reversed all male Nile tilapia (Oreocheromis niloticus) fingerlings, were purchased from a private tilapia hatchery in. Kafr El-Sheikh Governorate, Egypt. The experimental fish were transported at early moming using a special fish transport car with aeration facilities.

They seemed healthy and were acclimated to the experimental system condition 7 days before starting the experiment.

A total number of 750 sex-reversed all male Nile tilapia (Oreocheromisniloticus) fingerlings (25 fingerlings / tank, 3 tanks for control and 27 tanks for three experiments ) were distributed at random into four blocks (control and probiotics) experimental dietary, each block included control one were fed to fish basal diet in three tanks as triplicates and three treatments (three probiotic levels, and each level in three tanks as triplicates) and assigned for one of the three tested commercial probiotics, with initial average weights of $12.14 \pm .033,12.11 \pm .033$, 
$12.24 \pm .088,12.21 \pm 0.057,12.14 \pm .003,12.21 \pm .088$, $12.24 \pm .088, \quad 12.17 \pm .033, \quad 12.21 \pm .057$, And $12.24 \pm .033 \mathrm{~g} /$ fish, and with average total length of $8.50 \pm .057,8.43 \pm .033,8.48 \pm .11,8.50 \pm .12$, $8.50 \pm 0.057,8,47 \pm 0.057,8.43 \pm 0,17,8,46 \pm .14$, $8.44 \pm 0,00$, and $8,47 \pm .057 \mathrm{~cm}$ for D1, D2, D3, D4, D5, D6,D7,D8, D9, and D10, respectively, table (3) to study the effect of three commercial probiotics (Biogen, Premalac and Lacto Cel-con ) preparations supplemented to fish diets as growth promoters on the survival rate, growth performance, feed utilization efficiency, and immune response of monosex male Nile tilapia, Oreochromis niloticus fingerlings.

At the beginning and end of the experiment (10 fish) of the study fish from each tank were homogenized and analyzed for muscle composition according to A.O.A.C. (2000).

Streptococcus faecium, Aspergillusoryzae extract, Bifedobacteriumbifedumand Torula yeast (Premalac), Saccharomyces cerevisiae, Lactobacillus acidophilus and Enterococcus faecium (Lacto $\mathrm{Cel}$ - con ) to test their effect on the productive performance of Nile tilapia fingerlings. The composition of these four probiotic preparations, as claimed by the manufacturers, is as follow:

\section{Biogen:}

Biogen is a dried natural product composed of Allicin, High unit hydrolytic enzymes (proteolytic, lipolytic, amylolytic and cell separating enzymes), Bacillus subtilis and Ginseng extract.

It is stable for 24 months under room temperature conditions. It is worthy to note that, before introducing any of the above three commercial probiotics in the experimental diets, it was necessary to insure that these commercial products have really viable microorganisms.

\section{Premalac:}

It is a dried fermentation product of Lactobacillusacidophilus, Lactobacillus casei, Aspergillusoryzae extract, Bifedobacteriumbifedum, Streptococcus faecium, Torula yeast, skim milk, rice meal products, vegetable oil and calcium carbonate. It is stable for 24 months if kept in room temperature.

\section{Lacto Cel-con:}

Lacto Cel-con isa dried natural product each $1 \mathrm{Kg}$ contains of a good mixture of saccharomyces cervesia $\left(2 \times 10^{12} \mathrm{CFU}\right)$ in purified mature live cells with the most beneficial intestinal micro flora Lactobacillus acidophilus ( $100 \times 10^{9}$ CUF ) and Enterococcus faecium( $\left.70 \times 10^{9} \mathrm{CUF}\right)$, Carrier with mixture of ground yellow corn and gluten meal-in ratio 3:1.

\section{Ingredients:}

Yeast Culture (Active Saccharomyces cerevisiae Yeast grown and dogmatized on ground yellow com gluten meal, condensed fermented com extractives, cane molasses and malted barley), dried Lactobacillus acidophilus fermentation product, dried Enterococcus faecium fermentation product, dried Aspergillusoryzae fermentation extract, dried Aspergillusniger fermentation extract, dried Bacillus subtilis fermentation extract and Lactose .Experimental Design and Diets Formulation:

Three experimental studies were carried out to investigate the effect of three commercial probiotics as growth promoters on the performance and immune response of sex-reversed all male Nile tilapia (Oreocheromisniloticus) fingerlings.

A conventional yellow corn, soybeen meal (SBM)-fish meal and wheat bran basal diet was formulated to meet the minimum all nutrients required by Tilapia as recommended by the NRC (1993), and used with supplementation representing the control unsupplemented group (Table 1).

The basal diet was supplemented with three commercial probiotic preparations being Biogen, Premalacand Lacto Cel- con. Each one of these probiotics was applied in tilapia diets at three levels being 1,2 , and $3 \mathrm{~g} / \mathrm{kg}$ diet as recommended by the producers (Table 2 ). 
Which is considered as an indication for the viability of the microorganisms present viable in these commercial probiotics and so represents their growth promoting effect. Then, the feeding experiment started and durated for 90 days.

The dietary experimental ingredients were finely ground, weighed according to their percentage and then mixed together. Some warm water was added to each diet to be easily pelleted by pressing through $2 \mathrm{~mm}$ die by a meat mincer machine.

The pellets were dried in a drying oven at $60^{\circ} \mathrm{C}$ for 24 hours and crushed to adjust the diameter of pellets according to fish size and then stored at $-4^{\circ} \mathrm{C}$ to avoid oxidation and rancidity.

Accordingly, this experimental diet (isonitrogenous, 30\% CP and isocaloric ,4400 Kcal GE/kg.) contained 10th treatments groups including the control group which received the basal diet free of probiotic

\section{supplementation as follow:}

$\mathrm{D} 1=$ control $=$ group received the basal diet free of probiotic supplementation.

\section{First experiment:}

$\mathrm{D} 2=$ group received the basal diet $+1 \% \mathrm{~g} / \mathrm{kg}$ Biogen of probiotic supplementation.

** Gross energy value was calculated from their chemical composition, Estimated according to $\mathbf{N R C ( 1 9 9 3 )}$ as 5.64, 9.44 and $4.11 \mathrm{Kcal} / \mathrm{g}$ for protein, lipid and NFE, respectively.

\section{** Calculated by differences [Nitrogen free extract (NFE) = 100- $(\mathrm{CP}+\mathrm{EE}+\mathrm{CF}+\mathrm{Ash})]$.}

*** Estimated according to NRC (1993). ) as 5.64, 9.44 and 4.11 Kcal/g for protein, lipid and NFE, respectively.

D3 = group received the basal diet $+2 \% \mathrm{~g} / \mathrm{kg}$ Biogen of probiotic supplementation.

** Gross energy value was calculated from their chemical composition, Estimated according to NRC (1993) as 5.64, 9.44 and
4.11 Kcal/g for protein, lipid and NFE, respectively.

** Calculated by differences [Nitrogen free extract $(\mathrm{NFE})=100-(\mathrm{CP}+\mathrm{EE}+\mathrm{CF}+$ Ash $)]$.

*** Estimated according to NRC (1993). ) as 5.64, 9.44

$\mathrm{D} 4=$ group received the basal diet $+3 \% \mathrm{~g} / \mathrm{kg}$ Biogen of probiotic supplementation.

\section{Second experiment:}

D5=group received the basal diet $+1 \% \mathrm{~g} / \mathrm{kg}$ Primalac of probiotic supplementation.

D6=group received the basal diet $+2 \% \mathrm{~g} / \mathrm{kg}$ Primalac of probiotic supplementation.

$\mathrm{D} 7=$ group received the basal diet $+3 \% \mathrm{~g} / \mathrm{kg}$ Primalac of probiotic supplementation.

\section{Third experiment:}

D8= group received the basal diet $+1 \% \mathrm{~g} / \mathrm{kg}$ Lacto Cel-con of probiotic supplementation.

$\mathrm{D} 9=$ group received the basal diet $+2 \% \mathrm{~g} / \mathrm{kg}$ Lacto Cel-con of probiotic supplementation.

$\mathrm{D} 10=$ group received the basal diet $+3 \% \mathrm{~g} / \mathrm{kg}$ LactoCel-con of probiotic supplementation.

and 4.11 Kcal/g for protein, lipid and NFE, respectively.

\section{Feeding technique:}

Diets were fed to each group of fish during the experimental period .In the form of dried pellets suitable to fish size Feeding level was $4 \%$ of the total biomass of the fish /day.

Fish were fed 6 day/week and the amount of feed was divided into two equal portions at 9 am and 2 pm Every seven days, the fish in each tank were weighed and the amount of feed was corrected according to the new fish biomass throughout the experimental period (Annet, 1985).

The actual experimental feeding trials durated for a period of 3 months (90 days) Growth and feed utilization parameters: 
Table (1): Proximate Chemical analyses of the feed ingredients used in the experimental diets.

\begin{tabular}{lccccccc}
\hline Item & $\begin{array}{c}\text { DM } \\
\text { Ingredients }\end{array}$ & $\begin{array}{l}\text { CP } \\
\%\end{array}$ & $\begin{array}{l}\text { EE } \\
\%\end{array}$ & $\begin{array}{l}\text { CF } \\
\%\end{array}$ & $\begin{array}{l}\text { Ash } \\
\%\end{array}$ & $\begin{array}{l}* \mathbf{N F E} \\
\%\end{array}$ & $\begin{array}{l}* * \text { GE } \\
\text { (Kcal/kg DM) }\end{array}$ \\
\hline Fish meal & 92 & 65 & 9.6 & 0.7 & 19.4 & 5.3 & 4806 \\
Soybean meal & 90 & 44 & 1.1 & 7.3 & 6.3 & 41.3 & 4283 \\
Yellow corn & 88 & 8.5 & 3.6 & 2.3 & 1.3 & 84.3 & 4284 \\
Wheat bran & 89 & 16.4 & 4.0 & 9.9 & 5.3 & 64.4 & 3949 \\
\hline
\end{tabular}

* Calculated by differences [Nitrogen free extract (NFE) $=100-(\mathrm{CP}+\mathrm{EE}+\mathrm{CF}+\mathrm{Ash})]$.

As mentioned before, fish were weighed at weekly intervals (to minimize the effect of handling) as reported by Windell et al. (1978) and El-Banna (1991).

Fish were netted in a deep bodied net to be lifted from the water, allowed to drain for a full 5 seconds interval and put into a prepared container containing a known sufficient amount of water to eliminate any stress.

Total weight was determined to the nearest gram and the fish immediately returned to their tank conditions and the feed amounts were adjusted and corrected according to their weight (Annet, 1985).

The growth performance and feed utilization parameters included final weight gain (WG), average daily gain (ADG), specific growth rate (SGR),Survival rate (SR \%), Condition factor $(\mathrm{K})$ feed conversion ratio (FCR), protein efficiency ratio (PER), protein productive value (PPV), fat productive value (FPV), and energy utilization (EU) were calculated according to the following equations:

Final weight gain $(\mathrm{g})=$ final wt. $(\mathrm{g})$ initial wt. (g)Average daily gain (Castell and Tiews, 1980).

$\mathrm{ADG}=\left(\mathrm{W}_{1}-\mathrm{W}_{0}\right) / \mathrm{T}$
Where:

$\mathrm{W}_{0}=$ Initial body weight $(\mathrm{g})$.

$\mathrm{W}_{1}=$ Final body weight $(\mathrm{g})$.

$\mathrm{T}=$ Experimental period (days).

Specific growth rate (Pouomogne and

Mbongblang, 1993).

$\operatorname{SGR}(\% /$ day $)=\left(\ln \mathrm{W} 1-\ln \mathrm{W}_{0}\right) / \mathrm{T} \times 100$

Where:

$\mathrm{W} 1=$ final $\mathrm{wt}$.

$\mathrm{W}_{0=}$ initial $\mathrm{wt}$

$\mathrm{Ln}=$ Natural logarithm

$\mathrm{T}=$ period (days) Survival rate (SR \%)

$=$ Number of fish at final/Number of fish at startX100Condition factor (K): Estimated according to as:

$\mathrm{K}=\frac{\mathrm{W}(\mathrm{Kg})}{\mathrm{L}^{3}(\mathrm{~cm})} \times 100$

Where: $\mathrm{W}=$ fish weight

$\mathrm{L}=$ fish length 2.7.6.

Feed conversion ratio (Tacon, 1987):

$\mathrm{FCR}=$ Feed intake $(\mathrm{g}) /$ weight gain $(\mathrm{g})$ Protein efficiency ratio.

PER $(\%)=$ weight gain $(\mathrm{g}) /$ protein intake $(\mathrm{g}) \times 100$ Protein productive value. 
Table (2): Ingredients, proximate composition and calculated analysis of the formulated and basal diet used in the experimental diets (on DM basis)

\begin{tabular}{|c|c|c|c|c|c|c|c|c|c|c|}
\hline $\begin{array}{l}\text { Item } \\
\text { Ingredients }\end{array}$ & D1 & D2 & D3 & D4 & D5 & D6 & D7 & D8 & D9 & D10 \\
\hline Fish meal & 15 & 15 & 15 & 15 & 15 & 15 & 15 & 15 & 15 & 15 \\
\hline Soybean m56eal & 37 & 37 & 37 & 37 & 37 & 37 & 37 & 37 & 37 & 37 \\
\hline Yellow Corn & 28 & 27.9 & 27.8 & 27.7 & 27.9 & 27.8 & 27.7 & 27.9 & 27.8 & 27.7 \\
\hline Wheat bran & 10 & 10 & 10 & 10 & 10 & 10 & 10 & 10 & 10 & 10 \\
\hline Vit. Mix * & 2 & 2 & 2 & 2 & 2 & 2 & 2 & 2 & 2 & 2 \\
\hline Biogen g/kg & ---- & 0.1 & 0.2 & 0.3 & ---- & ----- & ----- & ----- & ------ & ----- \\
\hline Primalac g/kg & ---- & ----- & ----- & --- & 0.1 & 0.2 & 0.3 & ---- & ----- & ----- \\
\hline Lacto cel-con g/kg & --- & ----- & ----- & --- & ---- & ----- & ----- & 0.1 & 0.2 & 0.3 \\
\hline Linsed Oil & 4 & 4 & 4 & 4 & 4 & 4 & 4 & 4 & 4 & 4 \\
\hline Min.Mix & 1 & 1 & 1 & 1 & 1 & 1 & 1 & 1 & 1 & 1 \\
\hline $\begin{array}{l}\text { (CMC) carboxy methyl } \\
\text { celluleoe }\end{array}$ & 3 & 3 & 3 & 3 & 3 & 3 & 3 & 3 & 3 & 3 \\
\hline Total & 100 & 100 & 100 & 100 & 100 & 100 & 100 & 100 & 100 & 100 \\
\hline \multicolumn{11}{|c|}{ Chemical analysis and Nutritive value of the experimental diets ( on DM basis) } \\
\hline $\begin{array}{l}\text { Dry matter } \\
\text { (DM) } \%\end{array}$ & 91.9 & 90.0 & 88.0 & 92.4 & 92.4 & 88.0 & 92.4 & 92.4 & 93.2 & 92.2 \\
\hline $\begin{array}{l}\text { Crude protein } \\
\text { (CP) \% }\end{array}$ & 30.0 & 30.02 & 29.98 & 30.01 & 29.95 & 30.02 & 29.98 & 30.01 & 30.00 & 29.99 \\
\hline $\begin{array}{l}\text { Ether extract } \\
\text { (EE) } \%\end{array}$ & 7.25 & 7.24 & 7.20 & 7.23 & 7.22 & 7.19 & 7.18 & 7.13 & 7.16 & 7.22 \\
\hline $\begin{array}{l}\text { Crude fiber } \\
\text { (CF) } \%\end{array}$ & 4.44 & 4.42 & 4.43 & 4.41 & 4.44 & 4.39 & 4.43 & 4.38 & 4.41 & 4.40 \\
\hline Ash \% & 7.00 & 7.00 & 8.00 & 8.00 & 7.00 & 8.00 & 8.00 & 7.00 & 7.00 & 8.00 \\
\hline$* *$ NFE $\%$ & 51.31 & 51.32 & 50.39 & 50.35 & 51.39 & 50.40 & 50.41 & 51.48 & 51.43 & 50.39 \\
\hline$* * * G E(K c a l / k g)$ & 4485 & 4485 & 4441 & 4443 & 4483 & 4443 & 4439 & 4481 & 4481 & 4443 \\
\hline C/P \%ratio & 77.89 & 66.93 & 67.50 & 67.54 & 66.80 & 67.56 & 67.53 & 66.97 & 66.94 & 67.49 \\
\hline
\end{tabular}

* Vitamin \& mineral mixture/kg premix: Vitamin D, 0.8 million IU; E, 4g; k, 0.8g; B1, 0.4g; Riboflavin 1.6g; B6 0.6g 3B12, 4mg; Pantothenic acid, 4g; Nicotinic acid, 8g; Folic acid, 0.4g Biotin, 20mg, Mn, 22g; Zn, 22g; Fe, 12g; Cu, 4g; $1,0.4 \mathrm{~g}$, Selenium, $0.4 \mathrm{~g}$ and $\mathrm{Co}, 4.8 \mathrm{mg}$.

FPV $(\%)=$ Retained fat $(\mathrm{g}) /$ fat intake $(\mathrm{g})$

PPV $(\%)=$ Retained protein $(\mathrm{g}) /$ protein intake $(\mathrm{g}) \times 100$ Fat productive value: $\times 100$ Energy retention $(\%):($ ER $\%)=E-$ $\mathrm{E}_{\mathrm{O}} / \mathrm{E}_{\mathrm{F}} \mathrm{X}$ 100Where: 
$\mathrm{E}=$ the energy in fish carcass (kcal) at the end of experiment.

$\mathrm{E}_{\mathrm{O}}=$ the energy in fish carcass (kcal) at the start of experiment.

$E_{F}=$ the energy (kcal) in feed intake.

\section{Chemical analysis of feed:}

Periodical feed samples were taken for chemical analysis to insure that the composition of diets was stable during the experimental period.

The proximate analysis of each feed sample including moisture, crude protein $(\mathrm{CP})$, ether extract (EE), crude fiber (CF) and total ash content were determined according to (A.O.A.C. 2000) methods, while nitrogen free extract (NFE) was calculated by difference. Gross energy in feed samples were calculated from their chemical composition, estimated according to NRC (1993), as 5.64, 9.44 and $4.11 \mathrm{Kcal} / \mathrm{g}$ for protein, lipid and NFE, respectively.

\section{Chemical analysis of fish:}

At the beginning of feeding trial, a total number of twenty five fingerlings were netted, weighed and immediately kept in a deep freezer $\left(-18^{\circ} \mathrm{C}\right)$ for chemical analysis (as zero group).

Similar procedure was applied at the end of such experimental period (five fingerlings as final samples of each treatment). Zero group and the final samples of each treatment were separately dried at $65^{\circ} \mathrm{C}$ for $24 \mathrm{hrs}$. Then ground in a mixer.

Represtative samples were chemically analyzed according to (A.O.A.C. 2000) methods, while their energy contents were calculated according to (NRC 1993).

\section{The immune response of fish as affected by treatments:}

\section{Biochemical parameters:}

At the end of the experiment, 10 fish were taken from each tank and prepared for blood analysis.
The blood was obtained from the heart of the fish and the blood samples were collected in sterilized tubes, then kept in stating position at room temperature for 30 minutes, then in a refrigerator overnight, the separation of blood serum was completed by centrifugation for 20 minutes at 3000 r.p.m., blood Haemolysis was avoided.

Serum aspartate aminotransfears, AST $(\mathrm{u} / \mathrm{ml})$ and serum alanine amino transfears ALT $(\mathrm{u} / \mathrm{ml})$ were determined using commercial kits purchased from DIAMNOD DIAGNOSTIC Co. (Egypt). Colorimetric determinations of ALT and AST activity were determined based on the method developed by according to.

\section{Statistical analysis:}

The data of the present study were analyzed using the SAS Programme (2001) SAS/STAT User's guide Release 6.03 Edition SAS Inst. INC. Cary, NC, USA, considering the control group for comparison. Source and level of probiotics in experiment were the main comparison effects either for the feeding or the immunity experiments. Duncan's New Multiple Range Test was conducted to determine the significant differences between means (Duncan, 1955).

\section{Accordingly:}

In experiment, considering the control group without probiotic supplementation, the used model for analysis was:

$$
\mathbf{X}_{\mathrm{ij}}=\boldsymbol{\mu}+\mathbf{T}_{\mathbf{i}}+\mathbf{E}_{\mathrm{ij}}
$$

Where: $\mu$ is the overall mean.

$T_{i}$ is the effect of all treatments including the control. Ei is the experimental random error.

\section{RESULTS AND DISCUSSION}

Generally, no water quality problems were observed during the trial period. These means indicating that water quality parameters were within the acceptable range for mono-sex male Nile tilapia (O.niloticus) 
fingerlings growth (El-sayd,2006), and the experimental diets has a detrimental effects on the surrounding water quality criteria were the experimental fish had been stocked.

Therefore all experimental fish were in normal activity.This experiments were extended for 90 days using sex-reversed all male Nile tilapia (Oreocheromisniloticus) fingerlings.

It appears that all dietary treatments have commenced with a nearly similar initial body weight which ranged between $12.11 \pm 0.003$ and $12.24 \pm .088 \mathrm{~g} /$ fish, and initial body length which ranged between $8.43 \pm .033$ and $8.50 \pm .057 \mathrm{~cm} /$ fish.

Results revealed that averages of initial weights and lengths of the experiment start had insignificant differences among the experimental groups indicating that the complete randomization of individual fish among the experimental trials at the start of the experiment and were homogenous.

\section{Growth Performance, specific growth rate (SGR), Condition factor(K) and survival rate:}

The results of the average values of growth Performance, specific growth rate (SGR), Condition factor(K) and survival rate, of sex-reversed all male Nile tilapia (Oreocheromisniloticus) fingerlings, fed the Probiotics containing experimental diets are presented in Table (3).

At the end of the experimental period (90 days), the group of fish fed the supplemented diets grew as well or better than the group of fish fed the control diet. Whereas, the final body weight of the fish groups fed on diets $2,3,4,6,8,9$ and 10 had significantly $(\mathrm{P}<0.05)$ higher final body weight than the rest of the experimental groups.

However, the lowest final body weight was achieved by the groups of fish fed the control diet (D1). Growth performance in all treatment groups was better than control and Premlac group $(\mathrm{P}<0.05)$. At the end of experimental period three groups received by $3 \%$ Biogen and Lacto cel- Con showed increase in the body weight gain (BW), body length gain, specific growth rate (SGR), condition factor $(\mathrm{K})$ and survival rate $\%$ $(\mathrm{P}<0.05)$.

These results indicated that average values of growth Performance, specific growth rate (SGR), condition factor $(\mathrm{K})$ and survival rate, of sex-reversed all male Nile tilapia (Oreocheromis niloticus) fingerlings which received diets supplemented with Biogen and Lacto celCon at $3 \mathrm{~g} / \mathrm{kg}$ diet also exhibited the highest final live body weight, fish length, weight gain, daily weight gain, specific growth rate (SGR), condition factor $(\mathrm{K})$ and survival rate values.

These values were significantly higher than those obtained by fish having Premalac at 1 or $3 \mathrm{~g} / \mathrm{kg}$, however were a significantly different compared to the control group. The survival rate of fish fed with supplemented Biogen, Premalac and Lacto cel-Con showed no significant difference (100\%).

These results are in agreement with the results of Mehrim (2001) and Diab, et al (2002) for warm water fishes like Nile Tilapia (Oreocheromis niloticu). Khattab, et al (2004) and Mohamed et al., (2007) reported that Nile tilapia fingerlings fed on diets supplemented with probiotics exhibited greater growth performance and feed efficiency than those fed with control diet $(0 \%$ probiotic); these results are comparable with our results for Nile tilapia (Oreocheromis niloticu) fingerlings.

Similar results were reported by using bacteria as probitics which promote growth and feed efficiency. Moreover they also reported that Biogen ${ }^{\circledR}$ is an appropriate growth-stimulating additive in tilapia cultivation.

Yet, Mohamed et al. (2007) and Eid and Mohamed (2010) reported that $O$. niloticus fingerlings fed on diets supplemented with 
probiotics exhibited greater growth than those fed the control diet. Also, they added that the diet containing $30 \%$ protein and supplemented with Biogen ${ }^{\mathbb{B}}$ at level of $0.1 \%$ produced the best growth performance. Results of table (4) indicated that differences in D1 (control) among the experimental diets were significant $(\mathrm{P}<0.05)$.

On the other hand, the experimental fish fed on D3 (2 g/Kg Biogen ), D4(3 g/Kg Biogen ), D6 (2g/kg,Premalac),D8( $1 \mathrm{~g} / \mathrm{kg}$ Lacto Celcon),D9(2g/kg Lacto Cel-con),D10(3g/kg Lacto Cel-con) had a significantly $(\mathrm{P}<0.05)$ higher Feed intake, Daily Feed intake, feed conversion ratio, Feed efficiency and nutrients utilization of sexreversed all male Nile tilapia (Oreocheromis niloticus) fingerlings than the rest of experimental diets.

Whereas the lowest feed intake, Daily Feed intake, feed conversion ratio, Feed efficiency and nutrients utilization by experimental fish fed on control diet (Table 4). Also, showed a significant decrease in feed conversion ratio (FCR) in comparison with control group ( $\mathrm{p}<0.05)$.

All experimental diets contained treated commercial probiotic (Biogen* and Lacto Cel-con*) preparations supplemented to fish diets as growth promoters improved the feed utilization efficiency and increased the feed utilization efficiency significantly $(\mathrm{P}<0.05)$ of monosex male Nile tilapia, Oreochromisniloticus fingerlings (Table 4).

Results of protein efficiency ratio (PER) productive protein value (PPV \%), energy utilization (EU) and energy retention (ER) of Nile tilapia fed experimental diets containing treated Biogen* and Lacto Cel-con* are presented in table (4).

In Table (4), results revealed that Biogen* and Lacto Cel-con* experimental fish diets increased PER, PPV, EU and $\mathrm{ER} \%$ values significant $(\mathrm{P}<0.05)$.
The best FCR values observed with probiotics Biogen ${ }^{\circledR}$ and Lacto Cel-con supplemented diets suggested that addition of probiotics improved feed utilization. These result sfor probiotics use in diets for tilapia fingerling are in agreements with the findings of Bomba et al. (2002), Khattab et al. (2004) and Mohamed et al (2007).

In practical terms, this means that the use of probiotics can decrease the amount of feed necessary for animal growth which could result in reductions of production cost.

Results indicate that supplementing diets with probiotics significantly $(\mathrm{P}<0.05)$ improved protein utilization in commercial diets of tilapia.

In the present study (Table 4), protein efficiency ratio (PER), specific growth rate (SGR) and feed conversion ratio (FCR) improved by using, however, addition Biogen* and Lacto Cel-con to diet enhanced

The survival rate (SR) but different was not significant.

The improved fish growth and feed utilization may possible be due to improved nutrient digestibility. In this regard, Tovar et al. (2002), Lara-Florse et al. (2003), and Wachee et al (2006), found that the addition of live yeast improved diet and protein digestibility, which may explain the better growth and efficiency seen with yeast supplements. Also, AbdelTawwab et al. (2006), founded that the addition of S.cereviseain diet improvedprotein efficiency ratio of Oreochromisniloticus.

Effect of commercial probiotic on Carcass chemical composition and energy content of monosex male Nile tilapia, Oreochromis niloticus fingerlings.

Averages of Carcass chemical composition and energy content (on DM) basis of monosex male Nile tilapia, $O$. 
Table (3): Average values of growth Performance, specific growth rate (SGR), condition factor(K) and survival rate ,of sex-reversed Nile tilapia (Oreocheromis niloticus) fingerlings, fed the Biogen, Premalac and Lacto cel-con) containingexperimental diets (means \pm SD ).

\begin{tabular}{|c|c|c|c|c|c|c|c|c|c|c|}
\hline \multirow{4}{*}{$\begin{array}{l}\text { Treatment } \\
\text { Parameters }\end{array}$} & \multicolumn{10}{|c|}{ Experimental diets } \\
\hline & \multirow{3}{*}{$\begin{array}{c}\text { (D1- } \\
\text { Control) }\end{array}$} & \multirow{3}{*}{$\begin{array}{c}\text { (D2) } \\
(1 \mathrm{~g} / \mathrm{Kg}) \\
\text { Biogen }\end{array}$} & \multirow{3}{*}{$\begin{array}{c}(\mathrm{D3}) \\
(2 \mathrm{~g} / \mathrm{Kg}) \\
\text { Biogen }\end{array}$} & \multirow{3}{*}{$\begin{array}{c}\text { (D4) } \\
(3 g / K g) \\
\text { Biogen }\end{array}$} & \multirow{3}{*}{$\begin{array}{c}\text { (D5) } \\
\text { 1g/Kg } \\
\text { Premlac }\end{array}$} & \multirow{3}{*}{$\begin{array}{c}\text { (D6) } \\
\text { 2g/Kg } \\
\text { Premlac }\end{array}$} & \multirow{3}{*}{$\begin{array}{c}\text { (D7) } \\
\text { 3g/Kg } \\
\text { Premlac }\end{array}$} & \multirow{2}{*}{$\begin{array}{c}\text { (D8) } \\
1 \mathrm{~g} / \mathrm{Kg}\end{array}$} & \multirow{2}{*}{$\begin{array}{c}\text { (D9) } \\
\text { 2g/Kg }\end{array}$} & \multirow{2}{*}{$\begin{array}{l}\text { (D10) } \\
\text { 3g/Kg }\end{array}$} \\
\hline & & & & & & & & & & \\
\hline & & & & & & & & Lacto Cel-c & Lacto Cel-c & oilacto Cel-coI \\
\hline \multirow{2}{*}{$\begin{array}{c}\text { Init. fish } \\
\text { weight (g) }\end{array}$} & 12.14 & 12.11 & 12.24 & 12.21 & 12.14 & 12.21 & 12.24 & 12.17 & 12.21 & 12.24 \\
\hline & \pm .033 & \pm .003 & \pm .088 & \pm .057 & \pm .033 & \pm .057 & \pm .088 & \pm .033 & \pm .057 & \pm .033 \\
\hline \multirow{2}{*}{$\begin{array}{l}\text { Final fish } \\
\text { weight (g) }\end{array}$} & 53.64 & 55.74 & 62.81 & 67.03 & 51.91 & 55.10 & 50.12 & 59.61 & 65.81 & 70.71 \\
\hline & $\pm .43 \mathrm{~cd}$ & $\pm 0.35 \mathrm{c}$ & $\pm 0.55 \mathrm{~b}$ & $\pm .063 \mathrm{a}$ &, $\pm 69 \mathrm{c}$ & $\pm 1.73 \mathrm{a}$ & $\pm .057 \mathrm{c}$ & $\pm .46 \mathrm{c}$ & $\pm 1.21 \mathrm{~b}$ & $\pm .057 \mathrm{a}$ \\
\hline \multirow{2}{*}{$\begin{array}{c}\text { Init. fish } \\
\text { length (cm) }\end{array}$} & 8.50 & 8.43 & 8.48 & 8.50 & 8.50 & 8.47 & 8.43 & 8,46 & 8.44 & 8,47 \\
\hline & \pm .057 & \pm .033 & \pm .11 & \pm .12 & \pm 0.057 & \pm 0.057 & $\pm 0,17$ & \pm .14 & $\pm 0,00$ & \pm .057 \\
\hline \multirow{2}{*}{$\begin{array}{c}\text { Final } \\
\text { fishlength } \\
\text { (cm) }\end{array}$} & 13.50 & 13.93 & 14.00 & 14.25 & 13.11 & 13.20 & 13.12 & 13.95 & 14.25 & 14.50 \\
\hline & $\pm 0.17 \mathrm{c}$ & $\pm .17 \mathrm{~b}$ & $\pm .37 \mathrm{a}$ & $\pm .057 \mathrm{a}$ & $\pm 0.14 \mathrm{~b}$ & $\pm 0.17 \mathrm{a}$ & $\pm 0.19 \mathrm{~b}$ & $\pm .17 \mathrm{c}$ & $\pm .26 \mathrm{~b}$ & $\pm .094 \mathrm{a}$ \\
\hline \multirow{2}{*}{$\begin{array}{l}\text { Total weight } \\
\text { gain (g) }\end{array}$} & 41.50 & 43.63 & 50.57 & 54.82 & 39.8 & 42.8 & 37.9 & 47.44 & 53.60 & 58.47 \\
\hline & $\pm .64 \mathrm{~cd}$ & $\pm .066 \mathrm{c}$ & $\pm 1.44 \mathrm{~b}$ & $\pm 0.44 \mathrm{a}$ & $\pm 0.72 \mathrm{bc}$ & $\pm 1.67 \mathrm{a}$ & $\pm .14 \mathrm{c}$ & $\pm .46 \mathrm{c}$ & $\pm 1,27 \mathrm{~b}$ & $\pm .066 \mathrm{a}$ \\
\hline \multirow{2}{*}{$\begin{array}{l}\text { Av. daily } \\
\text { gain (g) }\end{array}$} & 0.46 & 0.48 & 0.56 & 0.61 & 0.44 & 0.47 & 0.42 & 0.53 & 0.60 & 0.65 \\
\hline & $\pm .005 \mathrm{c}$ & $\pm .0 .00 \mathrm{a} \mathrm{c}$ & $\pm .117 \mathrm{~b}$ & $\pm .017 \mathrm{a}$ & $\pm .005 \mathrm{bc}$ & $\pm .151 \mathrm{ab}$ & $\pm .003 \mathrm{bc}$ & $\pm .005 \mathrm{c}$ & $\pm .011 \mathrm{~b}$ & $\pm 0.01 \mathrm{a}$ \\
\hline SGR & 1.65 & 1.69 & 1.81 & 1.89 & 1.61 & 1.67 & 1.56 & 1.76 & 1.87 & 1.95 \\
\hline (\%/ day) & $\pm .014 \mathrm{~d}$ & $\pm .003 \mathrm{c}$ & $\pm .034 \mathrm{~b}$ & $\pm .034 \mathrm{a}$ & $\pm .017 \mathrm{c}$ & $\pm 0.031 \mathrm{a}$ & $\pm .008 \mathrm{~d}$ & $\pm .012 \mathrm{c}$ & $\pm .028 \mathrm{~b}$ & $\pm .003 \mathrm{a}$ \\
\hline \multirow{2}{*}{$\begin{array}{l}\text { Condition } \\
\text { factor }(K)\end{array}$} & 2.18 & 2.06 & 2,28 & 2,32 & 2.30 & 2.39 & 2,22 & 2.19 & 2.27 & 2.32 \\
\hline & $\pm .066 \mathrm{c}$ & $\pm .017 \mathrm{~d}$ & $\pm .11 \mathrm{ab}$ & $\pm 0.11 \mathrm{a}$ & $\pm .057 \mathrm{~b}$ & $\pm .014 \mathrm{a}$ & $\pm .080 \mathrm{c}$ & $\pm .057 \mathrm{c}$ & $\pm .061 \mathrm{~b}$ & $\pm .032 \mathrm{a}$ \\
\hline $\begin{array}{l}\text { No. of fish } \\
\text { at Start. }\end{array}$ & 25 & 25 & 25 & 25 & 25 & 25 & 25 & 25 & 25 & 25 \\
\hline $\begin{array}{c}\text { No. of fish } \\
\text { at end. }\end{array}$ & $24 a$ & $25 \mathrm{a}$ & $25 \mathrm{a}$ & $25 \mathrm{a}$ & 25 & 25 & 25 & 25 & 25 & 25 \\
\hline $\begin{array}{c}\text { Survival } \\
\text { ratio }(\text { SR\%) }\end{array}$ & $96 a$ & $100 \mathrm{a}$ & $100 \mathrm{a}$ & $100 \mathrm{a}$ & 100 & 100 & 100 & 100 & 100 & 100 \\
\hline
\end{tabular}

a, b..... Means within column with different superscripts are significantly different $(\mathrm{P}<0.05)$

niloticus fingerlings at the beginning and the end of the feeding experiments including dry matter (DM), crude protein $(\mathrm{CP})$, ether extract (EE), ash, and gross energy $(\mathrm{GE} \mathrm{kcal} / \mathrm{kg})$ are presented together in Table (5).

Averages DM contents of Carcass chemical composition and energy content of the experimental fish at the experimental diets start was $23.40 \pm 0.17$ and increased significantly $(\mathrm{P}<0.05)$ in all experimental diets groups at the end of the experiment.
There were no significant $(\mathrm{P} \geq 0.05)$ differences in dry matter, crude protein and ash of $O$. niloticus between $\mathrm{D}_{4}, \mathrm{D} 10$ and $\mathrm{T}_{1}$. While, there were significant $(\mathrm{P} \leq 0.05)$ decreased in both of ether extract and energy content in $\mathrm{D}_{4}$ and D10 compared with the control group $\left(\mathrm{D}_{1}\right)$. These positive effects in carcass composition of experimental fish may be due to the dietary supplementation with Biogen ${ }^{\circledR}$ and Lacto Celcon* which caused the good growth performance compared with the control group (Table 5). 
Table (4): Feed intake, Daily Feed intake, feed conversion ratio, Feed efficiency and nutrients utilization of sex-reversed all male Nile tilapia (Oreocheromisniloticus) fingerlings. fed the Probiotics containing experimental diets (means \pm SD),

\begin{tabular}{|c|c|c|c|c|c|c|c|c|c|c|}
\hline $\begin{array}{l}\text { Treatment } \\
\text { parameter }\end{array}$ & $\begin{array}{c}D_{1} \\
\text { Control }\end{array}$ & $\begin{array}{c}\text { D2 } \\
(1 \mathrm{~g} / \mathrm{Kg}) \\
\text { Biogen }\end{array}$ & $\begin{array}{c}\text { D3 } \\
(2 \mathrm{~g} / \mathrm{Kg}) \\
\text { Biogen }\end{array}$ & $\begin{array}{c}\text { D4 } \\
(3 \mathrm{~g} / \mathrm{Kg}) \\
\text { Biogen }\end{array}$ & $\begin{array}{c}\text { (D5) } \\
\text { 1g/Kg } \\
\text { Premlac }\end{array}$ & $\begin{array}{c}\text { (D6) } \\
2 \text { g/Kg } \\
\text { Premlac }\end{array}$ & $\begin{array}{c}\text { (D7) } \\
3 \text { g/Kg } \\
\text { Premlac }\end{array}$ & $\begin{array}{c}\text { (D8) } \\
1 \mathrm{~g} / \mathrm{Kg} \\
\text { Lacto Cel- } \\
\text { con }\end{array}$ & $\begin{array}{c}\text { (D9) } \\
2 \mathrm{~g} / \mathrm{Kg} \\
\text { Lacto Cel- } \\
\text { con }\end{array}$ & $\begin{array}{l}\text { (D10) } \\
3 \mathrm{~g} / \mathrm{Kg} \\
\text { Lacto } \\
\text { con }\end{array}$ \\
\hline $\begin{array}{l}\text { Feed intake } \\
\text { (g/fish) (FI) }\end{array}$ & $87.88 \pm 077 \mathrm{c}$ & $89.39 \pm 0.36 \mathrm{~b}$ & $92.80 \pm 0.45 \mathrm{a}$ & $94.45 \pm 2.55 \mathrm{a}$ & $78.45 \pm 2.55 \mathrm{c}$ & $83.39 \pm .36 \mathrm{~b}$ & $75.41 \pm .45 \mathrm{~d}$ & $90.50 \pm .003 \mathrm{c}$ & $94.4 \pm 1.48 \mathrm{~b}$ & $97.32 \pm 35 \mathrm{a}$ \\
\hline $\begin{array}{c}\text { Daily Feed } \\
\text { intake (DFI) }\end{array}$ & $1.22 \pm 0.011 \mathrm{bc}$ & $1.24 \pm .003 \mathrm{bc}$ & $1.28 \pm 0.005 \mathrm{~b}$ & $1.31 \pm 0.034 \mathrm{a}$ & $1.08 \pm .003 \mathrm{c}$ & $1.16 \pm .034 \mathrm{ab}$ & $1.05 \pm .005 \mathrm{c}$ & $1.26 \pm .003 \mathrm{c}$ & $1.31 \pm .023 \mathrm{~b}$ & $1.35 \pm .055 \mathrm{a}$ \\
\hline $\begin{array}{c}\text { Feed } \\
\text { conversion } \\
\text { ratio(FCR) }\end{array}$ & $2.11 \pm 0.023 \mathrm{a}$ & $2.05 \pm 0.12 \mathrm{~b}$ & $1.83 \pm 0.044 \mathrm{c}$ & $1.72 \pm 0.057 \mathrm{~d}$ & $1,97 \pm .012 \mathrm{~b}$ & $1.94 \pm .057 \mathrm{c}$ & $1.98 \pm .044 \mathrm{~b}$ & $1.91 \pm .015 \mathrm{~b}$ & $1.76 \pm .043 \mathrm{c}$ & $1.66 \pm / 005 \mathrm{~d}$ \\
\hline $\begin{array}{c}\text { Feed } \\
\text { efficiency } \\
(\mathrm{FE})\end{array}$ & $0.47 \pm .06 \mathrm{c} \mathrm{d}$ & $0.48 \pm 0.003 \mathrm{c}$ & $0.54 \pm 0.012 \mathrm{~b}$ & $0.58 \pm 0,017 \mathrm{a}$ & $0.51 \pm .003 \mathrm{a}$ & $0.51 \pm .017 \mathrm{a}$ & $0.50 \pm .012 \mathrm{~b}$ & $0.52 \pm .003 b c$ & $0.56 \pm .013 b$ & $0.60 \pm .003 \mathrm{a}$ \\
\hline $\begin{array}{c}\text { protein } \\
\text { efficiency } \\
\text { ratio (PER) }\end{array}$ & $1.57 \pm 0.017 \mathrm{~cd}$ & $1.63 \pm .005 \mathrm{c}$ & $1.82 \pm 0.039 \mathrm{~b}$ & $1.93 \pm 0.057 \mathrm{a}$ & $1.69 \pm .005 \mathrm{ab}$ & $1.71 \pm .057 \mathrm{a}$ & $1.67 \pm .039 \mathrm{c}$ & $1.75 \pm .018 \mathrm{c}$ & $1.89 \pm .049 \mathrm{ab}$ & $2,00 \pm .005 \mathrm{a}$ \\
\hline $\begin{array}{l}\text { Productive } \\
\text { protein value( } \\
\text { PPV \%) }\end{array}$ & $29,74 \pm 0.60 \mathrm{c}$ & $32.47 \pm 1.15 \mathrm{~b}$ & $36.64 \pm 0.88 \mathrm{~b}$ & $40.52 \pm 0.61 \mathrm{a}$ & $33.19 \pm 1.15 \mathrm{~b}$ & $34.57 \pm .61 \mathrm{a}$ & $33,11 \pm .88 \mathrm{bc}$ & $35,14 \pm 1.78 \mathrm{c}$ & $39,79 \pm 1.3 \mathrm{~b}$ & $42,99 \pm 1.08 \mathrm{a}$ \\
\hline $\begin{array}{c}\text { Energy } \\
\text { utilization } \\
\text { (EU) }\end{array}$ & $47 \pm 0.12 \mathrm{~d}$ & $50 \pm 0.05 \mathrm{c}$ & $53 \pm 0.006 \mathrm{~b}$ & $55 \pm 0.17 \mathrm{a}$ & $58 \pm 0.03 \mathrm{c}$ & $58 \pm 0.011 \mathrm{ab}$ & $61 \pm 0.09 \mathrm{a} b$ & $51 \pm 0.07 \mathrm{c}$ & $53 \pm 0.008 \mathrm{~b}$ & $55 \pm 0.19 a$ \\
\hline
\end{tabular}

a,b...Means within rows with different superscripts are significantly different $(P<0.05)$ 
Table (5): Proximate analysis of fish whole-body and energy content of sex-reversed all male Nile tilapia (Oreocheromis

niloticus) fingerlings as affected by incorporation of Biogen in the experimental diets (\% On Dry matter basis, Mean \pm S.D).

\begin{tabular}{|c|c|c|c|c|c|c|c|c|c|c|c|}
\hline Treatment & & & & & & At 1 & ie end & & & & \\
\hline Parameter & At the start & $\begin{array}{c}\text { (D1) } \\
\text { Control }\end{array}$ & $\begin{array}{c}\text { (D2) } \\
(1 \mathrm{~g} / \mathrm{Kg}) \\
\text { Biogen }\end{array}$ & $\begin{array}{c}\text { (D3) } \\
\text { ( } 2 \text { g/Kg ) } \\
\text { Biogen }\end{array}$ & $\begin{array}{c}\text { (D4) } \\
(3 \mathrm{~g} / \mathrm{Kg}) \\
\text { Biogen }\end{array}$ & $\begin{array}{c}\text { (D5) } \\
(1 \mathrm{~g} / \mathrm{Kg}) \\
\text { Premlac }\end{array}$ & $\begin{array}{c}\text { (D6) } \\
(2 \mathrm{~g} / \mathrm{Kg}) \\
\text { Premlac }\end{array}$ & $\begin{array}{c}\text { (D7) } \\
(3 \mathrm{~g} / \mathrm{Kg}) \\
\text { Premlac }\end{array}$ & $\begin{array}{c}\text { (D8) } \\
(1 \mathrm{~g} / \mathrm{Kg}) \\
\text { Lacto cel-con }\end{array}$ & $\begin{array}{c}\text { (D9) } \\
(2 \mathrm{~g} / \mathrm{Kg}) \\
\text { Lacto cel-con }\end{array}$ & $\begin{array}{c}(\mathrm{D} 10) \\
(3 \mathrm{~g} / \mathrm{Kg}) \\
\begin{array}{l}\text { Lacto cel- } \\
\text { con }\end{array}\end{array}$ \\
\hline $\begin{array}{c}\text { Dry matter } \\
\text { (DM \%) }\end{array}$ & $23.40 \pm 0.17 \mathrm{~d}$ & $28.18 \pm 0.05 \mathrm{c}$ & $28.92 \pm 0.11 \mathrm{~b}$ & $28.85 \pm 0.14 \mathrm{~b}$ & $29.33 \pm 0.32 \mathrm{a}$ & $28.92 \pm 0.11 \mathrm{~b}$ & $29.33 \pm 0.32 \mathrm{a}$ & $28.85 \pm 0.14 \mathrm{ab}$ & $29.11 \pm 0.15 b$ & $29.55 \pm 0.19 \mathrm{ab}$ & $29.71 \pm 0.51 \mathrm{a}$ \\
\hline $\begin{array}{l}\text { Crude protein } \\
\text { (СР\%) }\end{array}$ & $59.90 \pm 1.45 \mathrm{~d}$ & $62.10 \pm .57 \mathrm{c}$ & $64.53 \pm .33 b$ & $65.76 \pm 0.21 \mathrm{ab}$ & $67.12 \pm 1.45 \mathrm{a}$ & $63.33 \pm .33 \mathrm{~b}$ & $64.12 \pm 1.45 \mathrm{a}$ & $63.76 \pm 0.21 \mathrm{~b}$ & $65.32 \pm .23 \mathrm{~b}$ & $66.77 \pm 0.29 \mathrm{~b}$ & $67.92 \pm 1.59 \mathrm{a}$ \\
\hline $\begin{array}{c}\text { Ether extract } \\
\text { (EE\%) }\end{array}$ & $19.8 \pm 1.51 \mathrm{~d}$ & $25.20 \pm 0.33 \mathrm{a}$ & $24.57 \pm 0.27 \mathrm{~b}$ & $22.60 \pm 1.41 \mathrm{bc}$ & $21.08 \pm 0.67 \mathrm{c}$ & $25.37 \pm 0.27 \mathrm{~b}$ & $25.18 \pm 0.67 \mathrm{~b}$ & $25.10 \pm 1.41 \mathrm{~b}$ & $23.38 \pm 0.25 \mathrm{~b}$ & $21.45 \pm 1.22 \mathrm{c}$ & $20 . .11 \pm 0.71 \mathrm{~cd}$ \\
\hline Ash \% & $20.3 \pm 0.52 \mathrm{a}$ & $12.70 \pm 0.00 \mathrm{~b}$ & $10.90 \pm .33 \mathrm{~d}$ & $11.64 \pm 0.33 \mathrm{c}$ & $11.80 \pm 0.57 \mathrm{c}$ & $11.30 \pm .33 \mathrm{~b}$ & $10.70 \pm 0.57 \mathrm{~d}$ & $11.14 \pm .33 \mathrm{bc}$ & $11.30 \pm .52 \mathrm{bc}$ & $11.78 \pm .37 \mathrm{bc}$ & $11.97 \pm 0.63 \mathrm{~b}$ \\
\hline $\begin{array}{l}\text { Growth energy } \\
\text { (Kcal GE/g) }\end{array}$ & $5247.48 \pm 47.6 \mathrm{~d}$ & $5881,28 \pm 6.17 \mathrm{~b}$ & $5958,9 \pm 21.9 \mathrm{a}$ & $5842,2 \pm 47.6 \mathrm{~b}$ & $5775,5 \pm 21.9 \mathrm{c}$ & $5966,7 \pm 39.5 b$ & $5993,4 \pm 21.9 \mathrm{a}$ & $5965,5 \pm 60.8 \mathrm{~b}$ & $5891 \pm 54.5 \mathrm{a}$ & $5790,6 \pm 44.07 \mathrm{~b}$ & $5729 \pm 91.6 \mathrm{c}$ \\
\hline
\end{tabular}

a,b...Means within rows with different superscripts are significantly different $(\mathrm{P}<0.05)$ 
Results of the same table revealed that crude protein $(\mathrm{CP})$ in whole fish body at the experimental start was significantly $(\mathrm{P}<0.05)$ higher in the experimental diet (D4) than that of all experimental diets at the end indicating an increase in CP parallel are decrease in whole fish body ether extract (EE).

These results indicated in general that $\mathrm{CP} \%$ content in whole fish bodies is related to $\mathrm{EE}$ Contents where the increase in one is decrease on the costs of the other. Averages of whole fish bodies ash \% results revealed that ash $\%$ in whole tilapia bodies was significantly $(\mathrm{P}<0.05)$ highest at the initial of the experiment (20.3 \pm 0.52$)$ compared to those of all experimental diets at the end of the experiment (Table 5).

At the end of the experiment, the diet (D6) showed the lowest $(\mathrm{P}<0.05)$ ash \% (10.70 \pm 0.57$)$. The higher ash $\%(12.70 \pm 0.00)$ in the control diet (D1) used in the current study (Table 5).

As presented in the same table, energy contents as GE $\mathrm{kcal} / \mathrm{kg}$ dry matter at the initial of the experiment was found to be $5247.48 \pm 47.6 \mathrm{kcal} / \mathrm{kg}$ dry matter and it was increased significantly $(\mathrm{P}<0.05)$ to $5993.5 \pm 21.9$ $\mathrm{kcal} / \mathrm{kg}$ dry matter in the experimental diets D5, at end of the experimental period.

These results are in close agreement with the results of Diab et al. (2002), Lara-Flores et al. (2003), Mohamed et al. (2007) and Mehrim (2009).

Since, Biogen ${ }^{\circledR}$ can enhance the metabolism and energy of fish body cells and raise the efficiency of feeds (Mehrim, 2001). On the other side, results in the present study are in close agreement with those of Khattab et al. 2004), Srour (2004), EL-Haroun et al. (2006) for tilapia and EL-Haroun, (2007) for catfish.

Moreover, Eid and Mohamed (2008) found that no statistical differences were observed in whole body moisture, crude protein, ether extract and ash of mono-sex O. niloticus fingerlings fed diets containing different levels of commercial feed additives (Biogen ${ }^{\circledR}$ and Pronifer () , compared with the control treatment. Effect of commercial probiotic on the immune response (liver functions and survival rate of monosex male Nile tilapia, Oreochromisniloticus fingerlings.

Determining the immune response of experimental fish to the tested probiotics had been done in two measures being the mortality percentage and the Liver Enzymes testes of monosex male Nile tilapia, $O$. niloticus fingerlings.

The results of the differential count of the mortality percentage and the Liver Enzymes testes of monosex male Nile tilapia, $O$. niloticus fingerlings having the tested probiotics as an index for the immune response are listed in Table (6).

Results of Table (6) indicate that, supplementation of the basal diet with feed additives (probiotics) significantly $(\mathrm{P}<0.01)$ decreased serum levels of transferase enzymes (ALT and AST).

Fish fed the control diet showed the highest levels of (ALT and AST) while fish fed the diet supplemenmted with probiotics showed the lowest ones. These results indicate that probiotics removed the toxic factors of the diets and therefore improved liver function. Shalaby et al., (2003) found that activity of liver enzymes (ALT and AST) was markedly decreased in tilapia fed diets containing licorice roots than those fed the control diet.

El-Dakar et al., (2004) showed significant lower $(\mathrm{P}<0.05)$ ALT and AST activities with fish fed fennel seed meal in diets. The results could be attributed to the immune - modulatory effect of Probiotics on the liver cell which activate the anabolic capacity of the hepatocytes to produce blood protein particularly globulin (Jessus et al., 2002), and this was also supported by the results of hepatic enzymes activity which decreased in O. nilticus kept on probiotic in comparison to the control group. These results were supported by the findings of regarding the viability; the all experimental fish were in 
Table (6): Effect of Biogen*, Premalac and Lacto Cel-conpreparations supplemented to fish diets on the liver functions and survival

rate of monosex male Nile tilapia, Oreochromis niloticus fingerlings. (Mean \pm S.D).

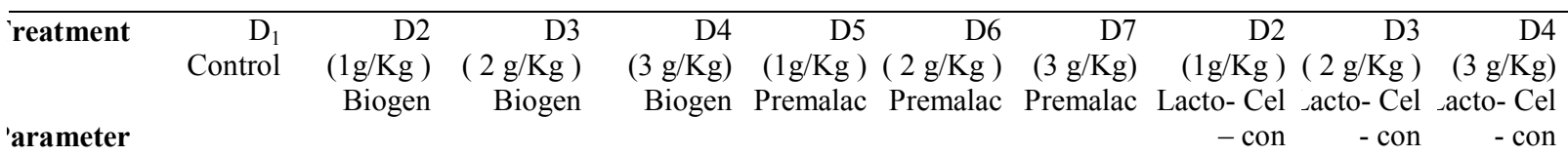

$\begin{array}{ccccccccccc}\text { SGOT } & 49.62 \pm 0.67 & 48.44 \pm 0.17 & 45.23 \pm 0.42 & 43.41 \pm 0.87 & 47.00 \pm .57 & 46.33 \pm .57 & 48.20 \pm .57 & 45.11 \pm .52 & 42.15 \pm .37 & 38.42 \pm .57 \\ \text { (AST) } & \mathrm{a} & \mathrm{b} & \mathrm{c} & \mathrm{d} & \mathrm{b} & \mathrm{c} & \mathrm{b} & \mathrm{ab} & \mathrm{a} & \mathrm{ab} \\ \begin{array}{c}\text { SGPT } \\ \text { (ALT) }\end{array} & 47.35 \pm 0.55 & 45.20 \pm .57 & 43.11 \pm 0.51 & 42.71 \pm 0.37 & 45.00 \pm .57 & 44.00 \pm .57 & 45.10 \pm .57 & 43.41 \pm .67 \mathrm{c} & 40.35 \pm .51 & 36.71 \pm .44 \\ \begin{array}{c}\text { ALrvival } \\ \text { rate }\end{array} & \mathrm{a} & \mathrm{b} & \mathrm{c} & \mathrm{d} & \mathrm{d} & \mathrm{a} & \mathrm{c} & & \mathrm{a} & \mathrm{b} \\ \text { (SR\%) } & 96 & 100 & 100 & 100 & 100 & 100 & 100 & 100 & 100 & 100\end{array}$

normal conditions and activity.

Under the prevailing conditions of water surrounded fish, the probiotics fed through diets, no mortality had been recorded at the end of the experimental groups.

However, there have been very few studies in aquaculture that focus on bacteria that prevent the growth of pathogenic microorganisms (Austin et al., 1995, Bergh, 1995, and Riquelme et al., 1997).

El-Dakar and Goher (2004) used B. subtilis in micro-binding diets for Penaeusjaponicus post-larvae. They found that the level of survival in response to bacterial challenge was high in shrimp fed the diet containing B. subtilis, while survival rate declined in the control shrimp fed the basal diet. Several mechanisms have been suggested as modes of action for probiotic bacteria.

The competitive exclusion mechanism, based on the substitution of pathogen by the beneficial population, has been considered to be important by many authors (Moriarty, 1998; Gatesoupe, 1999. and $\mathrm{Li}$ and Galtin, 2004).

In the present study, supplementation of the basal diet by Probiotics resulted in higher survival rate than fish fed the control diet. Mehrim (2001) reported that addition of 0.3\%

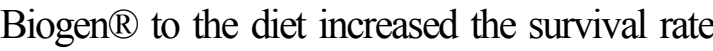

of tilapia compared with the control diet (without Biogen $®$ ).

El-Barbary (2002) showed that survival rate of Nile tilapia was increased as Biogen $\AA$ level increased from 0 to $0.4 \%$. The positive effect of Biogen ${ }^{\circledR}$ and Lacto cel-Con may be due to its probiotic effects which serve as antitoxic, antibacterial and antifungal agents, which may lead to improve the survival rate. Ghosh et al, (2007) indicated that incorporation of pobiotics (B. subtilis) in fish diets significantly increased survival and decreased fry mortality.

Biogen ${ }^{\circledR}$ can enhance the metabolism of fish body cells, raise the efficiency of feed utilization and balance the secretion of various secretary glands.

Moreover, it increases the vitality of cells by supplying oxygen to whole body and improves the immune responses (Diab et al., 2002), helps to excrete heavy metals, inhibits aflatoxin and stimulates the normal endocrine system.

\section{CONCLUSION}

In conclusion, all results obtained indicated that either Biogen or Lacto- Cel - con* at $3 \mathrm{~g} / \mathrm{kg}$ produced a positive effect on growth and feed utilization of tilapia fingerlings. 
In addition, the immune responses were substantial in both treatment groups following the challenge with bacterial disease. However, the probiotic Biogen or Lacto- Cel - con* when added to fish diet at $3 \mathrm{~g} / \mathrm{kg}$, produced a steady improvement of tilapia growth compared to Premalac.

Meanwhile, both were superior than using Premalac as commercial probiotics. Further studies are needed in this field as this strategy strengthens and help understanding the role of probiotics looking for the alternative health management strategy for developing aquaculture productivity.

\section{REFERENCES}

Abdel-Tawwab, M., Y.A.E. Khattab, M.H. Ahmad and A.M.E. Shalaby (2006). Compensatory growth, feed utilization, whole-body composition and hematological changes in starved juvenile Nile tilapia, Oreochromisniloticus (L.). J. Appl. Aquac., 18: 17-36.

Abo-State, H.A., Kh. F. El-Kholy and A.A. AlAzab (2009). Evaluation of probiotic $(\mathrm{EMMH})$ as a growth promoter for Nile tilapia (Oreochromisniloticus) fingerlings. Egyptian J. Nutrition and Feeds, 12(2): 347-358.

Ali HM, Ghazalah A. A., Gehad E. A., Hammouda Y. A., Abo-State H. A. (2010). Practical aspects and immune response of probiotics preparations supplemented to Nile tilapia (Oreochromis niloticus) diets Nature and Sci 8: 39-45.

Annet, C. S. (1985). A model to facilitate optimal aquaculture production by quantitatively relating fish growth to feed and other environmental resources. Ph.D., Thesis, Michigan State University, USA

AOAC., (2000). Association of Official Analytical Chemists of official methods of analysis, 17th Ed. Washington, DC. Barnes, M.E., D.J. Durben, S.G. Reeves and R. Sanders (2006). Dietary.
Austin B,Struckey Lf, Robertson PA, Effendi I, Friffith D. (1995). A probiotic strain of Vibrio alginolyticus effective in reducing diseases caused by Aeromonas salmonicida, Vibrio angillarum and Vibrio ordalii. Journal of Fish Diseases 18: 93-96.

Bergh,ф. (1995). Bacteria associated with early life stages of halibut, Hippoglossus hippoglossus L., inhibit growth of a pathogenic Vibrio Sp. J. Fish Dis., 18: 31 4.

Bomba A.; Nemcoa R.; Gancarc-Ova S.; Herich R.; Guba P. and Mudron-Ova D. (2002). Improvement of the probiotic effect of micro-organisms by their combination with maltodextrins, fructooligosaccharides and polyunsaturated fatty acids. British Journal of Nutrition, 88 (Suppl.1): 95-99.

Castell, J. D. and Tiews, K. (1980). Report of the EIFAC, IUNS and ICES working group on the standardization of methodology in fish nutrition research. Hamburg, fed. Rep. Germmany, 21-23. March 1979. EIFAC Tech. Pap., No.36, 24 pp.

Chang C. I., and Liu WY.(2002). An evaluation of two probiotic bacterial strains, Enterococcus faecium SF68 and Bacillus toyoi, for reducing edwardsiellosis in cultured European eel, Anguilla anguilla L.. J Fish Dis;25:311-5.

Diab, A. S., G. O. El-Nagar, and Y. M. AbdEl-Hady, (2002). Evaluation of Nigella sativa L. (Black seeds; Baraka), Allium sativum (garlic) and Biogen ${ }^{\mathbb{B}}$ as a feed additives on growth performance and immuostimulants of Oreochromis niloticus fingerlings. Suez Canal Vet. Med. J., 2002, 745-775. (ISSN: 1110-6298.

Duncan, D.B. (1955). Multiple range and multiple F-test. Biometrics, 11:1-42

Eid, A. and K. A. Mohamed, (2008). Effect of using probiotic as growth promoter in commercial diets for monosex Nile tilapia (Oreochromis niloticus) fingerlings. $8^{\text {th }}$ 
International Symposium on Tilapia in Aquaculture, Cairo, Egypt, 12-14 Oct., pp: 241-253. (ISBN: 978-1-888807-18-9).

Eid, A. and K. A. Mohamed, (2010). study the effect of using probioticson tilapia fingerlings, from Suaz Canal University.

El-Banna, R. A. A. (1991). Studies on some nutrients requirement for tilapia and its effect on performance Ph. D. Thesis, Fac. Vet. Cairo Univ.

El-Barbary, M. I. (2002). Studies on aflatoxin in Fish. Ph.D. Thesis, Faculty of Agricultural Sciences, AlMansourah University, Egypt.

El-Dakar, A. Y.; Hassanien G. D. I.; Gad, S. S. and Sakr, S. E. (2004). Use of medical and aromatic plants in fish diets: 2. Effect of dried basil leaves on performance of hybrid tilapia Oreochromis niloticus $\times \mathrm{O}$. aureus, Fingerlings. $3^{\text {rd }}$ Inter. Conf. on Anim. Production and Health in semi-Arid Areas, Suez Canal Univ.pp.265-277.

El-Dakar, A.Y. and Goher, T.M. (2004). Using of Bacillus subtilis in microparticulate diets for producing biosecure of Peneaus japonicus postlarvae. Agric. Sci. Mansoura Univ., 29 (12):6855-6873

EL-Haroun, E.R., A. MA-S Goda, and M.A. Kabir Chowdhury, (2006). Effect of dietary probiotic Biogen ${ }^{\circledR}$ supplementation as a growth promoter on growth performance and feed utilization of Nile tilapia Oreochromis niloticus (L.). Aquaculture Research, 37: 14731480.

El-Sayed, Abdel-Fattah, (2006). Tilapia Culture. CABI Publishing, Cambridge, MA, USA. 37

FAO (Food and Agriculture Organization). (2002). Antibiotic residues in aquaculture products. The state of world fisheries and aquaculture 2002. Food and Agriculture Organization of the United Nations.Pp.7483.
FAO.(2011). Food and Agriculture Organization of the United Nations: The State of World Fisheries and Aquaculture, Rome

Fuller, R. (1989). Probiotics in Man and animals- A review. J. App L. Bacterio L. 66-365-378.

Gafrd,(2006). Gernal Authority for Fish Resources Development Statistical analysis of total aquaculture production in Egypt. Ministry of Agriculture, Cairo, Egypt; [Arabic ed.].

Gatesoupe, F. J. (1999). The use of probiotics in aquaculture. Aquaculture180:147-165. Ghosh, S.; Sinha, A. and Sahu, C. (2007). Effect of probiotic on reproductive performance in femalelivebearing ornamental fish. Aquaculture Research, 38:518-526.

Hidalgo, M. C., A. Skalli, E. Abella, M. Arizcun and G. Cardenete. (2006). Dietary intake of probiotics and maslinic acid in juvenile dentex (Dentex L.): effects on growth performance, survival and liver proteolytic activities. Aquaculture Nutrition 12:256-266.

Irianto, A. and B. Austin (2002). Probiotics in aquaculture. J. Fish Dis., 25:633-642.

Jessus ortuno, Alberto cuesta, Alejandro Rodriguez, M.Angeles Eesteban and Jose Meseguer (2002). Oral administration of yeast, Saccharomyces cerevisiae, enhances the celluler innate immune response of gillhead seabream, Sparus aurata L. J. Veterinary immunology and immunopathology 85 , 41-50.

Jovanović, R., Mišĉević, M., Ćirković, M., Milošević, N., Ljubojević, D., (2011). Effect of probiotic to the production of one month old carp. 7. MeĊunarodni gospodarsko - znanstveni skup o ribarstvu; Hrvatsko ribarstvo na pragu EU, Riba kao funkcionalna hrana, Proceeding summary. Vukovar, Croatia, p 7-11. 
Khattab, Y.A.E., A.M.E. Shalaby, S.M. Sharaf, H.I. El-Marakby and E.H. Rizkalla, (2004). The physiological changes and growth performance of the Nile tilapia Oreochromis niloticus after feeding with Biogen ${ }^{\circledR}$ as growth promoter. Egypt, J. Aquat. Bio.and Fish., 8: 145158. (ISSN: 1110-6131).

Kozasa, M. (1986). Toyocerin (Bacillus toyoi) as growth promoter for animal feeding. Microbiology Aliments Nutrition 4:121135.

Lara-Flores, M., (2012). Effect of the inclusion of a bacterial mix (Streptococcus faecium and Lactobacillus acidophilus), and the yeast (Saccharomyces cerevisiae) on growth, feed utilization and intestinal enzymatic activity of Nile tilapia (Oreochromis niloticus). International Journal of Fisheries and Aquaculture, 2(4): 93-101.

Lara-Flores, M., M.A. Olvera-Novoa, B.E. Guzmán-Méndez and W. López-Madrid, (2003). Use of the bacteria Streptococcus faecium and Lactobacillus acidophilus, and the yeast Saccharomyces cerevisiae as growth promoters in Nile tilapia Oreochromis niloticus. Aquaculture, 216: 193-201.

Li, P. and D.M. Gatlin III (2004). Dietary brewers yeast and the prebiotic Grobiotic TM AE influence growth performance, immune responses and resistance of hybrid striped bass (Monrone chrypsops $\mathrm{X}$ M.saxatilis) to Streptococcus iniae infection. Aquaculture, 231: 445-456.

Li, P.; Lewis, D.H. and Gatlin, D.M. (2004). Dietary oligonucleotide influences immune responses and resistance of hybrid striped bass (Moronic chrysops $\times$ M. saxatilis) to Streptococcus iniae infection. Fish and Shellfish Immunol 16: 561-569.
Mehrim A.I. (2011). Effect of Dietary Supplementation of Biogen $\AA$ (Commercial Probiotic) on Mono-sex Nile tilapia Oreochromis niloticus Under Different Stocking Densities. (Mansoura University) (3) (3803).

Mehrim, A.I.M. (2001). Effect of some chemical pollutant on growth performance, feed and nutrient utilization of tilapia. M.Sc. Thesis, Saba- Basha Fac. of Agric., Alex. Univ.

Merrifield, D. L., A. Dimitroglou, A. Foey, S. J. Davies and R. T. M. Baker. (2010). The current status and future focus of probiotic and prebiotic applications for salmonids. Aquaculture 302:1-18.

Metchnikoff, E.(1907). "Lactic acid as inhibiting intestinal putrefaction," in The Prolongation of Life, Optimistic Studies, pp. 161-183, Mitchell

Mohamed, K.A., B. Abdel Fattah and A.M.S. Eid, (2007). Evaluation of using some feed additives on growth performance and feed utilization of monosex Nile tilapia (Oreochromis niloticus) fingerlings. Agricultural Research Journal, Suez Canal University, 7: 49-54. (ISSN: 1110-6999.

Moriarty, D. J. W. (1998). Control of luminous Vibrio species in penaeid aquaculture ponds. Aquaculture, 164:351-358.

NRC (National Research Council) (1993). Nutrient requirements of fish. Committee on Animal Nutrition Board on Agriculture.National Academy Press, Washington DC., USA. 114pp.

Panigrahi A, Kiron V, Puangkaew J, Kobayashi T, Satoh S, Sugita H.(2005). The viability of probiotic bacteria as a factor influencing the immune response in rainbow trout Oncorhynchus mykiss. Aquaculture; 243:241-54. 
Park, J.H.; Park, W.J. and Jeong, H.D. (2001). Immunological efficacy of Vibrio vulinficus bacterins given as an oral vaccine in the flounder, Paralichthys olivaceus Aquaculture, 201: 187-197.

Pouomogne, V. and Mbongblang, J. (1993) .Effect of feeding rate on the growth of tilapia (Oreochromis niloticus) in earthen ponds. Bamidgeh, 45: $147-153$.

Qi Z, Zhang H, Boon N, Bossier P.(2009). Probiotics in aquaculture of China-current state, problems and prospect. Aquaculture; 290:15-21.

Rengpipat S.; Rukpratanporn S.; Piyatiratitivorakul S. and Menasveta P. (2000). Immunity enhancement in black tiger shrimp (Penaeus monodon) by a probiont bacterium (Bacillus S11). Aquaculture, 191:271-288.

Ringo E, Oldsen RE, Gifstad TO, Dalmo RA, Amlund $\mathrm{H}$, et al. (2010). Prebiotics in aquaculture: review. Aquaculture Nutr 16: 117136.

Riquelme C, Araya R, Vergara N, Rojas A, Guaita M, Candia M. (1997). Potential probiotic strains in the culture of the Chilean scallop Argopecten purpuratus (Lamarck, 1819). Aquaculture; 154:17-26.

Salminen, S., A. Ouwehand, Y. Benno and Y. K. Lee. (1999). Probiotics: how should they be defined? Trends in Food Science and Technology 10: 107-110.

SAS (2001). SAS statistical guide for personal computer, SAS Institute Inc. Cary, NC.

Schrezenmeir, J. and M. De Vrese.(2001). Probiotics, prebiotics, and synbiotics-approaching a definition. American Journal of Clinical Nutrition 73:361-364.

Shalaby, S. M.; Abd Elmonem, A. I. and El-Dakar, A. Y. (2003). Enhancement of growth performance, feed and nutrient utilization of Nile tilapia,
Oreochromis niloticus, using of licorice roots (Erksous) as a feed attractive. J. Egypt. Acad. Soc. Environ. Develop. (B-Aquaculture), 4 (2):119-142.

Shelby, R.A., C. Lim, M. Yildirim and P.H. Klesius (2006). Effects of probiotic bacteria as dietary supplements on growth and disease resistance in young channel catfish. Intalurus punctatus (Rafinesque). J. of Applied Aquaculture, 18(2): 49 - 60.J. Animal and Poultry Prod., Mansoura Univ., Vol.3 (6), june, 2012

Srour, T.M., (2004). Effect of ochratoxin-A with or without Biogen $^{\circledR}$ on growth performance, feed utilization and carcass composition of Nile tilapia (Oreochromis niloticus) fingerlings. J. Agric. Sci. Mansoura Univ., 29: 51-61. (ISSN: 11100346).

Tacon, A. (1987). The nutrition and feeding of farmed fish and shrimp a training manual. V 61. 1. The essential nutrients. FAO.PP. 117- 130.

Tovar, D., J. Zambonino, C. Cahu, F.J. Gatesoupe, R. Vazquez-Juarez and R. Lesel (2002). Effect of yeast incorporation in compound diet ondigestive enzyme activity in sea bass (Dicentrarchus labrax) larvae. Aquaculture, 204: 113-123.

Villamil, L., Figueras, A., Planas, M., Novoa, B., (2003). Control of Vibrio alginolyticus in Artemia culture by treatment with bacterial probiotics Aquaculture 219, $43-45$.

Vine, N. G., W.D. Leukes, and H. Kaiser, (2006). Probiotics in marine larviculture. FEMS Microbiol Rev., 30: 404-427.

Waché, Y., Auffray, F., Gatesoupe, F.J., Zambonino, J., Gayet, V., Labbé, L. \& Quentel, C. (2006). Cross effects of the strain of dietary Saccharomyces cerevisiae andrearing conditions on the onset ofintestinal microbiota and digestive enzymes in rainbow 
trout,Onchorhynchus mykiss, fry. Aquaculture 258, 470-478.

Wang, W. (2007). Effect of probioticson growth performance anddigestive enzyme activity of theshrimp Penaeus vannameiAquaculture, 269, 259-264.
Windell, J. T.; Foltz, J. W.; Sarokon, J. A. (1978). Methods of fecal collection and nutrient leaching in digestibility studies.Prog.Fish Cult. 40: $51-55$. 


\section{الملخص العربى}

تأثيرات استخدام مستويات مختلفة من بعض الاضافات الحيوية كمنشطات للنمو فى العلائق على أداء

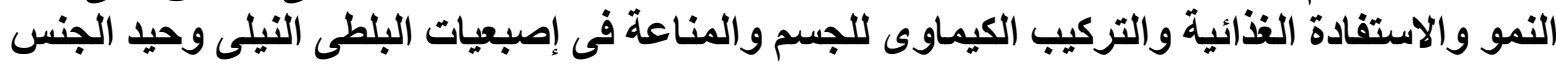

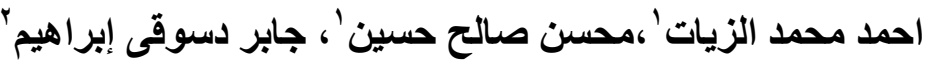

1 ـ قسم الإنتاج الحيو انىـ كلية الزر اعةـ جامعة الأز هر بالقاهرة

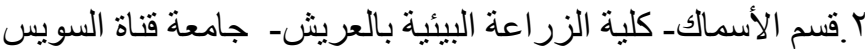

أجريت هذه التجارب فى الأحواض الفيبرجلاس فى المزرعة السمكية التجريبية بنظام اعادة استخدام المباه المغلقة

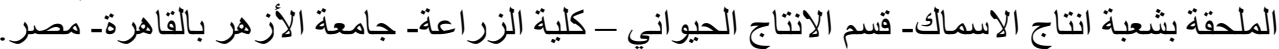

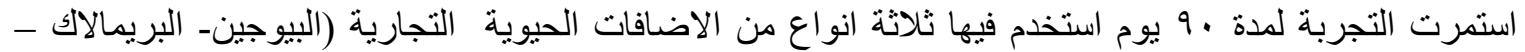

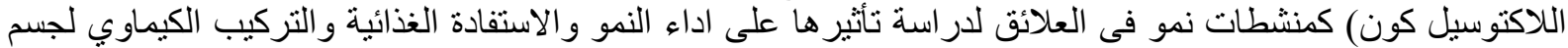
الأسماك و المناعة فى اصبعيات اسماك البلطى النيلى وحيدة الجنس (ذكور). وكل اضافة حيوية تم تطبيقه فى العلائق الاساسية للبلطى على ثلاث مستويات ا، r ، ب جر ام / كجم عليقة وذللك حسب توصية منتجيها و التجارب تم تحلئه تيلها احصائياً.

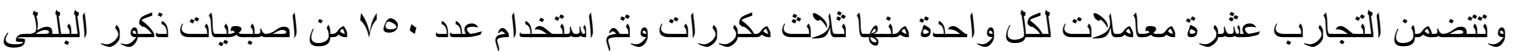

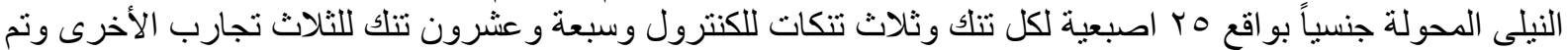

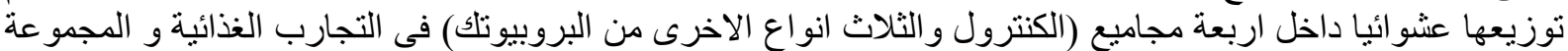

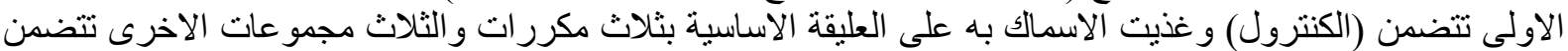

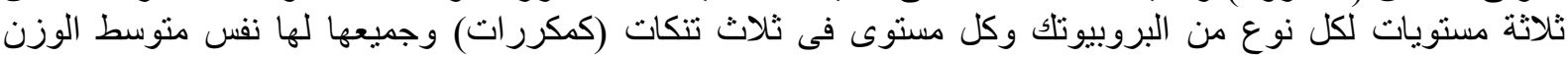

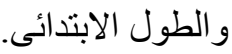

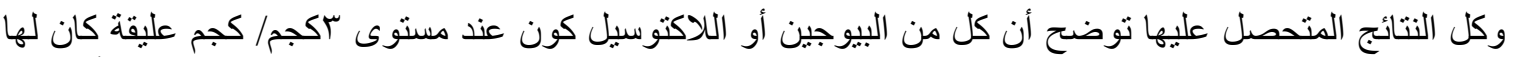

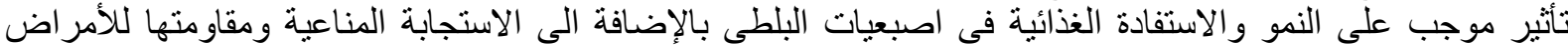

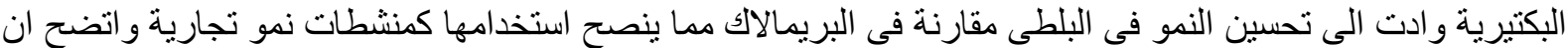

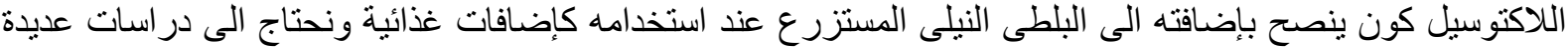
فى هذا المجال للمساعدة فى فهم البروبيوتلك كإضافات غذائية صحية لتطوير كفاءة الاستزر العاع المائي. الكلمات الإسترشادية : البروبيوتلك، منشطات النمو، الاستفادة الغذائية ،التركيب الكيماوي للجسم إصبعيات البلطي النيلى وحيد الجنس (ذكور).

اـ أ.د/ سمير إبراهيـــ غنيم أستاذ بقسم تكنولوجيا علوم الأغذية و الالبانـ كلية العلوم الزر اعية البيئية بالعريش، جامعة قناة السويس. ץ- أ.د/ مالكك محمد السيد خلف الله أستاذ مساعد بقسم الاستزر اع السمكي، كلية الزر اعة، جامعة كفر الثيخ. 